\title{
Insights into the Indian Call Centre Industry: Can Internal Marketing help tackle high employee turnover?
}

\author{
1Pawan S Budhwar \\ Aston Business School \\ Birmingham B4 7ET, UK \\ Tel: 0044-121-204-3049 \\ Fax: 0044-121-204-3327 \\ Email: p.s.budhwar@aston.ac.uk \\ Arup Varma \\ Graduate School of Business - HRIR \\ Loyola University Chicago \\ Chicago, IL 60611USA \\ Tel: 001-312-915-6664 \\ Email: avarma@luc.edu \\ Neeru Malhotra \\ Aston Business School \\ Birmingham B4 7ET, UK \\ Tel: 0044-121-204-3151 \\ Fax: 0044-121-204-4917 \\ Email: n.malhotra@aston.ac.uk
}

\author{
Avinandan Mukherjee \\ Professor of Marketing \\ Montclair State University \\ School of Business \\ Montclair, NJ 07043, USA. \\ Tel: +1-973-655-5126 \\ Fax: +1-973-655-7673
}

Email: mukherjeeav@mail.montclair.edu

\section{Journal of Services Marketing, 35(5) (Forthcoming)}

${ }^{1}$ Corresponding Author

Acknowledgement: This research is funded by ESRC grant - RES-000-22-1876. We greatly appreciate this support and also thank the participating firms for all their cooperation with data collection. 


\begin{abstract}
Purpose - Increasing turnover of frontline staff in call centres is detrimental to the delivery of quality service to customers. This paper presents the context for the rapid growth of the business process outsourcing (BPO) sector in India, and addresses a critical issue faced by call centre organisations in this sector - the high employee turnover.

Design/methodology/approach - Following a triangulation approach, two separate empirical investigations are conducted to examine various aspects of high labour turnover rates in the call centre sector in India. Study one examines the research issue via 51 in-depth interviews in as many units. Study two reports results from a questionnaire survey with 204 frontline agents across 11 call centres regarding employee turnover.

Findings - Our research reveals a range of reasons - from monotonous work, stressful work environment, adverse working conditions, lack of career development opportunities; to better job opportunities elsewhere, which emerge as the key causes of increasing attrition rates in the Indian call centre industry.
\end{abstract}

Research limitations/implications - Our research suggests that there are several issues that need to be handled carefully by management of call centres in India to overcome the problem of increasing employee turnover, and that this also demands support from the Indian government.

Originality/value - The contributions of this study untangle the issues underlying a key problem in the call centre industry, i.e. employee turnover in the Indian call centre industry context. Adopting an internal marketing approach, we provide useful information for both academics and practitioners and suggest internal marketing interventions, and avenues for future research to combat the problem of employee turnover.

Keywords: call centres; frontline employees; employee turnover; internal marketing; India, HRM

Paper type: Research paper 


\section{Introduction}

A clear shift from manufacturing to knowledge-based services industries is emerging across the world. Scholars in Marketing and HRM are giving increasing attention to the personal interaction between the customer and the employee on the 'frontline' of service businesses (Mattson, 1994). A key problem for service organizations has been attracting and retaining high quality employees (Heskett et al., 2008).

Business process outsourcing (BPO) enabled by call centers and informational technology enabled services (ITeS) are becoming an important part of the mushrooming service industry. Rapid developments in information technology, economies of scale; along with an increased emphasis on customer satisfaction are perhaps the most important factors contributing to the quick growth of the call centre industry (Brown and Maxwell, 2002; Tuten and Neidermeyer, 2004). For example, in UK alone, more than 10 million customers use telephone banking (see Forsyth, 2004). It is estimated that 1000 jobs outsourced from the UK to India can help save up to 10 million pounds annually to respective organisations. Similarly, outsourcing to India can free up to $\$ 30$ billion for new investments in the US (see The Economic Times, 2005; The Hindu, 2005a).

Huge cost savings (estimated 30-50 percent) coupled with rapid developments in both information technology and software development, and availability of a large number of trained professionals speaking fluent English, have resulted in India becoming the preferred destination for BPO (see Chengappa and Goyal, 2002; Ramchandran and Voleti, 2004; Prahalad, 2005). At present, over 400 of the Fortune 500 companies either have their own centres in India, or outsource to Indian firms. Further, it is estimated that India controls 44 percent of world outsourcing business (NASSCOM, 2005a). Based on these data, NASSCOM (National Association of Software and Services Companies - the agency responsible for ITeS sector in 
India) predicts that as many as 10 million jobs will be available to Indians in the service sector by 2009 (Bagchi, 2005). Clearly, the Indian call centre industry seems to have tremendous future potential given its forecasted annual growth rate of 40-50 percent for the next five years (The Economist, 2004; Sify.com, 2005; The Economic Times, 2005; Cacanas, 2004).

However, there is another side to the phenomenal success story of the Indian call centre industry. As the industry is evolving, emerging media reports highlight a number of problems, which can seriously impact the high growth rates predicted for this sector. These include issues such as increasing employee turnover, stressful work environment and poor career development (see Walletwatch, 2003; Singh, 2005a), which are not very different from the problems experienced by call centres in other parts of the world (Singh, 2000; Tuten and Neidermeyer, 2004; Robinson and Morley, 2006). However, additional problems like poor infrastructure and concerns for security are also coming to light in the Indian call centre industry context (see Singh, 2005a). In this connection, it should be noted that this sector is still in its infancy stage in India (4-5 years old), and hence there remains paucity of research on possible aspects of BPO industry in India. Given the irreversible involvement of a large number of both national and multinational firms, and the significant impact of Indian call centre industry on the world economy, it is crucial to highlight the problems faced by the industry and suggest possible ways to combat the same. In this paper, we discuss issues relating to one of the most common and crucial problems experienced by the call centre sector in India, i.e., increasing employee turnover, its implications and suggestions on how to tackle this growing problem.

The main aims of this paper are threefold. First, to highlight the key problems faced by the Indian Call Centre industry and the primary reasons behind these. Second, to empirically examine and analyse the scenario related to high employee turnover in this sector. Third, to 
present a series of recommendations from an internal marketing perspective (Rafiq and Ahmed, 2000), which could help organisations address the problem of growing employee turnover.

\section{The Indian Call Centre Industry - Overview and Emerging Problems}

Before highlighting the main problems experienced by call centres operating in India, it is useful to provide an overview regarding the developments in the sector. This will help to explain the context, which is perhaps responsible for the emerging problems.

As indicated above, the emergence of India as a key BPO destination is a relatively recent phenomenon - only 4-5 years old. However, its roots go back a few years - to the mid 1990s, when the Indian information technology and software sector (ITSS) was evolving. A combination of factors was responsible for the development of ITSS. Perhaps the two most important factors leading to the growth of the ITSS sector were the high-quality academic institutions in India, and the liberalisation of Indian economy in 1991 (see Budhwar, 2001). Indeed, India has a strong tradition of engineering institutes, which over the decades have produced high quality graduates. Nevertheless, it was the liberalisation of the Indian economy that opened the gates for foreign investors, and provided plenty of opportunities at home for the large number of indigenous talented human resources. Several other factors have led to the emergence and success of call centres in India. Among these, (i) the existence of ITSS and call centre industry, (ii) the availability of large talent pool of skilled graduates, (iii) a strong base of blue-chip companies, (iv) powerful venture capital investments in growth opportunity, (v) development of track record of proven delivery and systems/processes, (vi) significant government support to the sector, (vii) improved international bandwith situation, (viii) competition among state governments to attract BPO investments, (ix) a number of tax incentives (e.g., export services are largely tax free), (x) the time difference between India and main clients 
(based in the US and UK), along with comparative national cost advantage have contributed significantly to the rapid growth of the call centre industry in India (see Prahalad, 2005; Ramchandran and Voleti, 2004; Punch, 2004; The Economist, 2004; 2005; Chengappa and Goyal, 2002; Read, 2001).

The future of the Indian call centres is predicted to be very promising. The exports generated are projected to rise to $\$ 20$ billion by 2007 from $\$ 565$ million in 2000 . Further, Morgan Stanley reports that BPO to India is expected to earn export revenue of $\$ 62$ billion by 2010. India stands far ahead of its nearest competitors (i.e., Ireland and the Philippines) regarding total number of employees employed in the sector, total number of firms involved in $\mathrm{BPO}$, the revenue earned by the industry, the rapid move towards 'high value' jobs (e.g., KPO Knowledge Process Outsourcing - typical users include market research agencies, consulting firms, investment banks, legal firms, automotive companies and corporate planning department) and the number of English-speaking graduates available (see for example, Punch, 2004; Shastri, 2004; Chengappa and Goyal, 2002). Globally, the KPO pie is estimated to touch $\$ 25$ billion by 2010 and India is expected to command a 60 percent of its market share (see The Economic Times, 2005; Chanda, 2005). Further, the employment in the sector is projected to rise from its current level of 300,000 to over 1.1 million by 2008 (NASSCOM, 2005a).

On the other hand, all is not well for the call centres in India. Some of the key barriers to growth as reported in the media and NASSCOM reports, include (i) relatively poor electricity and telecom infrastructure, (ii) lack of customer service culture, (iii) cultural differences between employees and clients, (iv) under-trained operators speaking English with a heavy accent, (v) scarcity of language skills other than English; (vi) employees with relatively little work experience (vii) increasing automation of customer interaction technologies, (viii) regional political instabilities, (ix) long time taken to get government's clearance to allow foreign firm to 
start operations, (x) increasing competition from other low-cost options such as the Philippines, China, Eastern Europe, South Africa; and (xi) increasing costs (for more details see Pande, 2005; Christopher, 2005; Rediff.com, 2005a; 2005b; Sangameshwaran and Rai, 2005; NASSCOM, 2005b). The impact of such constraints is clearly demonstrated by the fact that a number of operators in the business have gone bankrupt in the recent past (see Businessline, 2005).

Interestingly, the emerging reports highlight that the main reason for the closure of some firms has nothing to do with company's clients or competition - rather, the primary reason seems to be the poor management of human resources and lack of internal marketing philosophy. The site director of Tracmail - one of the earliest call centres that set base in India - summarises this as follows: "Our strengths have become our weakness and our weaknesses have become strengths". He elaborates on this by highlighting that 'in the past, providing real time offshoring and getting good telecom connectivity was seen as a challenge. At the same time, a strong middle management team and employees were considered strengths. At present, the reverse is true'. He further comments that "unless this industry attains maturity fast, it will die”.

In this connection, it should be noted that by end 2008, the BPO sector is expected to fall short by roughly 262,000 people, despite the regular turnaround of approximately three million graduates trained by Indian universities each year. As a result, the gap between abilities and skills will increase substantially. Perhaps the most challenging problem experienced by the call centre industry is employee turnover, and retention of talent. Different sources highlight different turnover rates in the Indian call centre industry - reported to be anywhere between 20-70 percent, although NASSCOM and call centre managers tend to put the figure around 15-25 percent. Similar observations are made in outsourcing call centers operating in developed nations, where company officials report turnover rates between 20-30 percent, but informally admit to it being much higher (Taylor and Bain, 1999). Some recent research (see Singh, 2005a; Taylor and Bain, 
2005) has argued that the turnover rates are higher than reported by company officials, and this is also a critical problem faced by call centres operating in India.

HR managers in the sector report to be hiring people almost on a daily basis. In specific BPO zones, like the Mindspace complex in suburban Mumbai, employee turnover has led to a popular joke, i.e. "if you reach the wrong floor, you'll be recruited" (Sangameshwaran and Rai, 2005). The following stories reported in the media confirm the need for such an aggressive hiring and the 'silly reasons' contributing to high turnover rates.

Call centre managers have startling tales to tell. "A 20-something youth quit his banking firm recently on the grounds that the canteen in the office was not good". Another "girl moved out a company because her best friend got a job in a rival company'. Further, 'a 25-year-old is on his third job in as many months because he keeps getting better pay'. The youths also skip training sessions, and in some cases even miss regular office hours, just as they used to do in college days. Indeed, the overall culture seems to be one "where everything goes" (for more details see Jha, 2005; Sangameshwaran and Rai, 2005; Punch, 2004; Subramanyam, 2004). This scenario resembles the mid 1990s when the Indian economy started booming, and job-hopping was not only at its peak, but to some extent was seen as 'fashionable' (see Khatri et al., 2001). However, in the Indian call centre industry, the problem of high turnover is much deeper than simple job-hopping.

The director of the HR consulting firm People Equity points out a number of reasons unique to the call centre work environment that lead to high turnover. These range across a gamut of human issues which include odd working hours, working days/holidays determined by geographic considerations, assuming pseudo identities, learning foreign accent, operating in an alien environment, altered social and family life, harboring the risk associated with working in a 
fledging industry, high burn-out rates, lack of abilities of employees to handle work-life balance, job disillusionment, and less scope for personal growth (Shushmul, 2005; Punch, 2004).

With plenty of jobs on offer, youngsters also get carried away by complacency and an insouciance that is representative of their age group. About 87 percent of the workforce in call centres is below the age of 30 years, consisting mostly of college graduates looking for highgrowth opportunities, high salaries and a "great work environment" (see Jha, 2005). Due to the infancy stage of the sector, firms struggle with pre-recruitment background checks to clearly identify and select more reliable employees (Verma, 2005).

Reports highlight that call centre employees are experiencing a number of health, social and psychological problems, which mitigate the positive impact of any internal marketing activities carried out by the organisations to motivate these employees(see for example, Walletwatch, 2003; Cacanas, 2004; Singh, 2005b; Witt et al., 2005; Rose and Wright, 2005; Houlihan, 2004). For example, some call centre employees are asked to assume multiple identities and this is now shown to be causing psychological problems. Further, employees are asked to change names, acquire foreign accent(s), and develop new interests and hobbies to better converse with, and satisfy clients. This often causes the problem of 'multiple personality' disorder (identity disorder as a disturbance in identity) and, at present, firms do not seem to be concerned by the long term impact of such issues (for more details see Rajawat, 2005). This scenario is further complicated by the 'graveyard shifts' to match working hours in the Western hemisphere. These erratic working hours make normal socialisation difficult, leading to alienation, withdrawal, and increased irritability. Further, exposure to different cultures at a young age contributes to 'conflicting value systems' often leading to identity crisis among the young call centre employees. Psychologists note that many young individuals employed in call centres are vulnerable to burn-out stress syndrome (BOSS), symptoms of which include chronic 
fatigue, insomnia and alteration of the body's 24-hour biological rhythm (see George, 2005). Further, both disturbed sleep and prolonged working hours may lead to gastric ulcer, high blood pressure, diabetes or clinical depression (see Wadhwa, 2004). Other ailments ranging from hypertension, asthma to spondylitis are also reported as an outcome of working in call centres (Jayaswal, 2005).

Another critical factor contributing to the stress of working for an Indian call centre is that of racial abuse from irate overseas customers. Indeed, frontline staff face a spectrum of rudeness from sexual harassment to fury at unsolicited sales calls to open racism (The Hindu, 2005b; Baliga, 2005). In this connection, an interesting development needs to be mentioned. The industry has provided increased job opportunities for women in call centres- however, in a fairly conservative country like India, women are not expected to work during night shifts. The industry, of course, requires that employees work during the night shifts. As a result, this often leads to family and social problems. (see Financial Express, 2005; Aneja, 2005).

To summarise, the existing and emerging literature addressing high turnover in the Indian call centre industry can be divided into two categories - push and pull. Some of the prominent “push” factors include stressful work environment, monotonous work, long commutes, a sense of powerlessness or lack of control at work, daily physical confinement, over-regimentation (the feeling of being spied), odd work hours, and abusive clients. On the other hand, the main "pull" factors include a good job market, good pay, world class working conditions, knowing someone who already works in the business, and a well-known brand name. No matter what the reason, what is becoming clear is that high turnover among call centre employees is proving to be very costly for the industry as a whole.

Due to high turnover, companies are required to hire more aggressively, resulting in a gradual loss of the basic 'cost-effective' model of Indian call centres. In a job-seekers market, 
wages continue to rise at $10-20$ percent leading to a decline in average revenues. The cost for hiring new talent is continuously going up. For example, in 1999, the average monthly pay packet of an entry level agent was Rs. 7000 - 8000. In 2005, it is reported to be between Rs. 13,000 - 15,000 (1USD = 44 Indian Rupees approximately). Further, every departing employee costs the company another Rs 40,000 to 50,000 in replacement costs. Indeed, finding the right candidate is now becoming a problem. At present, for every 100 applicants in Mumbai, just one or two make the cut. Four years ago the success rate was 20 percent (Rediff.com, 2005a; 2005b; Sangameshwaran and Rai, 2005).

In such circumstances, the managers are under intense pressure from international clients to increase and maintain the employee count. Although, all new employees are provided jobspecific training, there is a reasonable time-lag before they achieve the required standards of onjob efficiency. Turnover thus has a tremendous impact on the 'delivery model of quality' and customer satisfaction, as the 'average handling time' for a specific operation shoots up when an entirely new person starts a job (for details see Singh, 2005a). Due to the fear of not getting enough "right people at the right time," some firms have started to maintain a 'rostering buffer' for scheduling manpower. Such firms are aiming for a 10 to 15 percent surplus staff on their rolls because although the office is open all seven days, employees work five-day weeks, and this is further affected by high turnover. Industry sources claim that attrition levels in call centres are sky-high, and any given firm could be looking at an entirely new set of employees every three to ten months (see Sangameshwaran and Rai, 2005). Ironically, many Indian firms have started to hire foreigners and are even taking their operations overseas because of the inevitable employee turnover problem faced by them (see Jayachandran, 2005). Clearly, such emerging problems have adverse implications for the Indian call centre industry. According to DiamondKluster International (a global management consulting firm), the number of clients prematurely 
terminating an outsourcing relationship has doubled to 51 percent, while the number of clients satisfied with their offshoring providers has decreased from 79 percent to 62 percent (see Pande, 2005; Christopher, 2005).

Being a people intensive sector, call centres need to pay special attention to the internal marketing activities. They must attract, retain and keep employees motivated and committed at all times (see Rafiq and Ahmed, 2000; Cooper and Cronin, 2000; Deery and Kinnie, 2004), since a certain amount of tenure is required to achieve service excellence (Schneider, 1991), which, in turn, ensures delivery of high quality service to customers (Schneider and Bowen, 1995). As the Indian call centre industry is still evolving, and the problems are still emerging, there is a paucity of empirical research, which can provide a clear picture of the complete scenario. In this connection, the existing literature reveals that most studies on outsourcing contact centres have been conducted in developed countries only (see for example, special issues of HRMJ, 2002; European Journal of Work and Organizational Psychology, 2003; International Journal of Service Industry Management, 2000; Holtgrewe et al., 2002; Bain and Taylor, 1999; Singh, 2000; Sergeant and Frenkel, 2000; Deery and Kinnie, 2004; Tuten and Neidermeyer, 2004; Brown and Maxwell, 2002).

A few of these studies have examined the problems faced by employees in the call centres. For example, Rubery et al. (2004) examine employment issues and employment relations in the context of a UK based call centre. Witt et al. (2005) examine the interaction between emotional exhaustion and conscientiousness and their effect on performance of customer service representatives (CSRs) in a US call center. Hannif and Lamm (2005) examine the occupation health and safety in the New Zealand call center industry. Lewig and Dollard (2003) examine issues related to emotional dissonance, emotional exhaustion and job satisfaction in call center workers. Along similar lines, Grebner et al. (2003) look at working conditions, well-being 
and job-related issues of agents in the call center industry. Robinson and Morley (2006) address the issue relating to metrics employed in call centres for performance evaluation, which exacerbates the conflict between the twin objectives of achieving cost-efficiency and servicing customers adequately. Some studies examine the effect of issues related to empowerment, organisational commitment, stress and satisfaction on employee performance and retention in the outsourcing firms (see, Batt, 1999; Singh, 2000; Sergeant and Frenkel, 2000; de Ruyter et al., 2001; Russell, 2002; Kinnie et al., 2000; Taylor and Tyler, 2000; Taylor et al., 2002; Malhotra and Mukherjee, 2004; Mukherjee and Malhotra, 2006; Dean, 2004; Halliden and Monks, 2005; Rose and Wright, 2005; Cordray, 2005;). However, none of the studies conducted so far examine the issue of employee turnover in call centres at length in the Indian context.

\section{Methodology}

Considering the exploratory nature of the research, a triangulation approach (comprising in-depth interviews and questionnaires) was adopted for the study. Study 1 is based on in-depth interviews with senior members of the HR team(s) from 51 call centres operating in India. The data were collected from between December 2006 and April 2007. On average, the interviews lasted for about an hour. For this paper, information on demographics, organizational structure, attrition and retention is content analysed, and at places direct quotes are used.

For Study 2, a questionnaire-based survey was conducted with 204 'on-floor' or 'frontline' agents across 11 call centres. The majority of the firms (60 percent) included in our research established their operations in India after 2002. Almost all the sample firms (98 percent) serve overseas clients.

Most of these units are based in and around New Delhi, the capital of India. Based on discussions with call centre employees, a questionnaire comprising nine sections was developed. 
These sections cover issues related to working conditions, pay and incentives, job enrichment, customers, health, relations with colleagues, commitment level, performance appraisals and career development. A total of 28 statements relating to employee turnover, and intent to turnover, were used. The operators were asked to rate these statements on a 1-5 rating scale where 1 = 'strongly disagree' and $5=$ 'strongly agree'. In addition, participants were asked to provide up to three main reasons for the high turnover rate in the call centre sector.

\section{Results and Discussion}

Work Organisation

A brief description of the way work is organized in these call centres is presented below, to help explain the working conditions. The units included in our study are involved in a range of activities including customer care, risk management, remote maintenance, supply chain management, data conversion, inventory management, web development, personal loans, and HR related activities (e.g. recruitment).

The physical layout of the workplace in most call centres involves large offices with individual compartmentalised workstations. The operators are trained to interact with clients using a telephone/computer system, and the work requires long hours of phone conversation, which follows a specific protocol. Strict quality control measures are in place - including both remote call monitoring, and on-floor supervisors. On average, a single supervisor may monitor up to 12 operators. All calls are monitored for accent, language, content of conversation, and satisfaction of clients.

Most sample firms follow a work shift of eight hours, with strict timing for facilities breaks. In order to better serve the US and UK based clientele, many frontline staff work at night, thus taking advantage of the time difference. Almost all follow a traditional organisational 
structure consisting of several vertical levels. The HR department typically has about 20 staff members, and in roughly 84 percent of these firms, HR is represented at the board level. Interestingly, over three-fourths of these firms reported viewing HR as a strategic partner, through its involvement in the strategic planning process. Prior investigations of HR practices (e.g., Budhwar and Sparrow, 1997) in India have revealed a much lower level of HR involvement in strategy.

\section{HR issues in Indian Call Centres}

Our interviews revealed the adoption of a formal and structured approach to activities such as recruitment, training, compensation and appraisals. Most firms continue to report experiencing a number of problems. For example, in connection with recruitment, each vacancy attracts hundreds of applications, resulting in a very expensive and time consuming process for identifying right candidate. Also, at times, the candidates selected do not take up the job after a formal offer is made, as they are made counter offers by competitors. Similarly, despite having systematic and formal programs for training and development, HR managers report several problems with their training programs. These include budget constraints, lack of quality training providers, not enough time for employees to come on training due to pressure to start work and absence of trainees. Further, there seems to be limited emphasis on post-training evaluation. The comments of one training manager sum up the training scenario of call centres operating in India.

"I think overall our basic approach is very pragmatic, but somewhere a less than satisfactory experience exists in terms of post training effectiveness, --- I would like to see a very strong link between the need identification, offering the training and post-effective solutions in place for a person to be effectively doing that ---”. 
In connection with performance evaluations, most sample firms have a monthly or a quarter-based appraisal system. All the firms have a structured format and a clear set of guidelines for appraisals. Almost all the firms use some kind of rating scales, grading or ranking system, and set targets for appraisals. As most employees are not used to such strict appraisal systems, managers find it hard to implement it. The comments of the HR manager from one of the participating firms summarises this as follows:

“-- implementation of appraisal is something which nobody likes, --- we have to at times have to be tough, which people do not like doing, doing the tough part of evaluating a person is something that people do not like”.

Interviewees also report that the present appraisal system to be relatively less participative, perhaps, a more participative approach could be beneficial (as experienced by some call centres operating in India).

\section{Employee Turnover in Indian Call Centres}

During the in-depth interviews, managers were specifically asked to comment on (i) the turnover rates in the Indian call centre industry, (ii) the severity of the problem, (iii) the possible reasons behind the high employee turnover, (iv) the relationship between increasing employee turnover and aspects of quality of life and work-life balance, (v) the impact of employee turnover on the firms, (vi) the internal marketing interventions, if any, introduced to reduce turnover, and (vii) their recommendations for increasing employee commitment.

Not surprisingly, all the sample firms noted that high attrition was one of the key challenges faced by the organizations. While the turnover rates reported in the emerging literature vary (see Singh, 2005b; Taylor and Bain, 2005), there is no doubt that this is fast 
becoming an issue of serious concern for these organizations. Ironically, in spite of their emphasis on high-tech processes, these call centres are often referred to as 'new-age sweatshops', and the people working there as 'cyber coolies.' To some extent, this categorisation is justified, given that the bulk of their employees are fresh college graduates, with little or no experience, thus having little chance of climbing up the corporate ladder (see, e.g. George, 2005). Of course, such categorization of work in call centre environments is not limited to developing countries similar observations have been made for operations in developed nations where, once again, work is tightly controlled (see Callaghan and Thompson, 2002). As such, one might argue that the working conditions in Indian call centres resemble the 'electronic sweatshop image' proposed by Frenkel et al. (1998). This image of a tightly-controlled high-tech sweatshop is often the reason some individuals decide to terminate their employment. An HR manager in one of the Indian call centres had this to say:

"Some employees leave due to dissatisfaction with the work culture, or because their friends moved to other call centres, this usually happens with first timers in the call centre industry".

When asked about the three main motivators for frontline employees, money (good salary), career opportunities, and work environment emerged as the three key factors that attract individuals to work in call centres. Not surprisingly, these are also the primary factors that individuals use in deciding to accept alternate employment. So, if an individual operator feels he can get a higher salary or a more pleasing environment in another call centre, he or she moves on. Given that the call centre business is still in its nascent stages in India, there are numerous new outfits being established. This provides ample opportunity for employees to find alternate employment. Of course, from an organization perspective, this leads to high turnover, and the resultant replacement costs. 
Another important factor contributing to the high attrition rates is the nature of call center work. The monotonous nature of work, combined with night shifts, is leading to several health, social, and psychological problems, leading to the call for better "quality of life" and "work-life balance” programs. In the beginning, young employees find the work culture very attractive (especially the night life culture), however, after a while the taxing work schedule and environment starts to take it toll.

What is surprising, however, is that despite the severity of the ever increasing turnover problem, many managers report that their organisations have been very slow to respond. This is perhaps due to the fact that in a large country like India, the supply of qualified labor exceeds the demand. However, the ever-increasing replacement costs, disruption of work due to separations, and the problem of finding an appropriate replacement in a timely fashion is a serious issue that needs to be addressed in a comprehensive fashion. Table I presents responses of operators to the questionnaire items.

\section{Take in Table I}

In Study 2 - the questionnaire-based survey - participants were asked to suggest up to three main causes of increasing employee turnover in the Indian call centres. It should be noted that the participants in the survey phase were the actual operators/ frontline employees in the call center operations, as opposed to the managers who were included only in the interview phase of our research. However, we were pleased to note that the results from the survey mirror our findings from the interviews. The key findings from the survey are listed below, in order of priority (i.e., based on how many participants listed each as a key factor).

The most important factor that emerged as a key reason for high turnover rates is the limited growth and career development opportunities in the call centre industry. As noted above, the managers we interviewed had also suggested that this was a key factor determining intent to 
leave. The second most important factor was the nature of the work itself - repetitive and monotonous. Some respondents noted that the call centre work was not very different from the traditional assembly lines in manufacturing organizations. Indeed, our findings confirm the existence of a bureaucratic and highly controlled environment, where the employee has little or no autonomy, once again mirroring the 'electronic sweatshop image’ proposed by Frenkel et al. (1998). It should be pointed out that these findings are contrary to those reported in some studies conducted in call centre operations in the West (see, e.g. Hutchinson et al., 2000) where call centres have adopted high commitment practices resulting in the (perceived) empowerment of employees.

The third key factor specifically related to the unique working conditions in the call centre environment. Given that most of the Indian call centres service clients in the western world, a key requirement is working at night, to take advantage of the time difference. This seems to create a lot of problems for individuals who are married or have family responsibilities, such as taking care of parents. The unique working hours make it difficult to lead a normal social life, leading to alienation and identity crisis. Indeed, several employees reported severe physical and psychological ailments developed as a result of working night shifts and having to deal with impatient and angry customers.

The fourth key factor seems to be directly related to the type of work involved in these call centres. Since the work does not call for highly specialized skills, organizations reportedly rely more on "trainability" of the employee, rather than looking for individuals with specific competencies. While this makes it college graduates from any discipline to get call centre jobs, it also makes it easier for them to switch companies. Indeed, the issue of 'employee poaching' has become a 'hot' topic of discussion in call centre industry and related media. Given the 
continuing growth of this sector, organisations will need to work on retention techniques and interventions to address this problem.

Finally, several participants noted that management did not treat all employees equally (or fairly) - instead, they noted experiencing the creation of in-groups and out-groups, whereby individuals in managers' in-groups received special favours (e.g., better assignments, higher ratings, etc.; see Varma, et al., 2005, for a discussion of in-groups and out-groups).

Clearly, these are critical issues in retaining employees, and creating an efficient and effective workplace. There does seem to be some evidence of organisational efforts toward addressing the above concerns. As one HR manager noted:

"We do have various schemes and incentives etc. One is that we use are 'fast track programs'. Here the potential performers, good performers, get moved on to a fast track and fast track essentially means that you may jump levels; you may get higher responsibilities than many others. Another is what we call 'hot skills program', here people with skills which are very much in demand in the market get paid better than others and the list of the skills gets published every year, people can acquire those skills and move into that segment. These programs have helped us a great deal”.

Furthermore, the sample firms provide a competitive compensation package, developed in response to market trends. They also report collecting market wage data on a regular basis, and bench marking their packages against the best payers. Also, a few employee involvement initiatives, which have reported success in the west (see Wilkinson, 1998; Heller, 1998) are also being adopted in the Indian call centres. Indeed, employee participation may contribute to employees' growth needs and a sense of achievement through better utilization of their skills and potential. Table II summarises these findings. 
Take in Table II

\section{Conclusions and Recommendations - Internal Marketing}

As we see the growth of call centre industry in India, policy makers are recognizing the issues that need to be addressed to ensure sustained growth of this mushrooming business. Given the significant positive impact that this business has had on the Indian economy, it is not surprising that the government and the corporate sector are closely collaborating on addressing such issues. However, our research shows that several organisations are too caught up in their day-to-day activities, to be able to spare time to take the long-term view. Undoubtedly, part of this phenomenon is an artifact of the nascent stage of the industry in India. However, issues related to high employee turnover, and the psychological, health and stress related problems of frontline employees need to be addressed at the early stages, in order to promote healthy growth of this sector. For example, at present, less than 4 percent of training time in call centres is spent on stress management (see Business line, 2003), even though our research clearly demonstrates that it is one of the fastest growing problems of employment in this business. Perhaps the biggest contributor to the increasing employee turnover in call centres is the design of work itself-- very formal and bureaucratic. While there is no doubt that this is partly necessary given the nature of the industry, the long term success of these organizations will depend on their ability to manage their human resources effectively and efficiently.

From the organisational perspective, the need of the hour is a well-structured and rationalised internal marketing approach that can significantly improve employee relations with management and overall organisational competitiveness and performance. Only then can these organisations hope to respond to the challenges presented by globalisation. Internal marketing would help these firms to attract and retain qualified human resources who deliver excellent 
service to customers. In the context of problems faced by call centres, it becomes imperative for these call centre organisations to find out what they can do, as part of the internal marketing strategy, to ensure that the frontline employees remain committed, and provide quality service to satisfy their customers.

Since satisfaction of internal customers, i.e. employees, is linked to satisfaction of external customers (Heskett et al. 2008), internal marketing aims at satisfying the needs and wants of 'internal customers', so that they display the right attitude and remain committed, which is crucial for delivering good quality service and satisfying customers. According to Berry and Parasuraman (1991, p. 151), "Internal marketing is attracting, developing, motivating and retaining qualified employees through job- products that satisfy their needs.” Cooper and Cronin (2000) state that "Internal marketing consists of an effort by the organisation to train and motivate its employees to provide better service” (p. 177). Hence, it seems that internal marketing constitutes a critical interface between marketing and human resource management (Quester and Kelly, 1999), and its implementation requires cross-functional co-ordination between the human resources and marketing departments (Rafiq and Ahmed, 2000). Thus, internal marketing implies applying the practices of marketing to the people who serve the external customers, so that quality staff can be employed and retained (Greene et al., 1994).

Based on our analyses of interview and survey data, and drawing from various media reports, we propose the following internal marketing interventions that are likely to help reduce high turnover rates in Indian call centres.

1. Employee Harassment Prevention: One of the key issues that need to be addressed by both, the government and call centre management is protecting frontline employees, and women in particular, from sexual and racial abuse received from overseas clients. Several respondents listed this as a key determinant of their intent-to-turnover. Indeed, it is heartening to note that some call 
centres have started developing 'black lists' of abusive clients, and putting them on their 'do not call list' (see Baliga, 2005). Furthermore, company sponsored provision of psychological support (e.g., Employee Assistance Programs) is a must for harassed employees, as most employees are young and do not have skills that would allow them to cope with this kind of abuse.

2. Industry Specific Training Programs: The projected growth of call centres and the concurrent shortage of skilled workers in the call centre industry in India suggest the need for training programs specific to the needs of the industry. For example, media reports estimate a potential demand for over 160,000 foreign language professionals in the Indian call centres by 2010, while only 40,000 qualified individuals are projected to be available. Clearly, this will create a supplyside constraint (Jayachandran, 2005). As such, both the government and institutions of learning need to step in and create programs that will help minimise this gap.

3. Career Planning: There is also a need for career planning. In order for organisations to attract and retain qualified candidates, organisations need to address issues beyond the obvious "pull" factors such as high pay. Since most call centres lack opportunities for promotion and advancement (Stanworth, 2000; Belt, 2002), many career-minded employees leave, thus further exacerbating the problem of employee turnover. With properly developed career progression models, recruiters may be able to convince qualified candidates to consider call centres as a career option, not just a job. Opportunities for advancement and career development are crucial, since they form an integral part of the HRM practices that aim to foster organisational commitment among employees (Meyer and Smith, 2000) and help reduce turnover.

4. Innovative Recruitment: Call centres also need to move beyond the traditional methods of recruitment (i.e., newspaper advertisements) that are very popular in India. Instead, they need to explore and employ new channels of hiring, such as job portals on the internet, walk-ins, and employee referrals (see Subramanayam, 2004). Indeed, Progeon (BPO venture of Infosys) has successfully instituted a rather unique method of recruitment called the 'campus ambassador 
program,' whereby a student in a particular college is hired as the ambassador. This student then gets a thorough briefing on the call centre industry and the inner workings of the organisation. He or she is then required to spread the word amongst his/her co-students. Furthermore, call centres should also consider hiring older (even retired), and disabled individuals, as they are less likely to leave, yet may be fully qualified to handle these jobs.

5. Eliminate Accent Training: One common feature of many of the call centres is the accent training provided to the operators, so as to make the calling customer believe that he or she is speaking to someone close by. As noted above, this often leads to identity crisis for the operators, as well as psychological problems. Ironically, it is common knowledge now that when one makes a service call, the respondent may be sitting half-way across the world. As such, it may be time for call centres to eliminate the artificial accent training, and allow employees to speak with their natural accent. It should be noted that there is a strong request from several quarters to address this issue.

6. Fun in the Workplace: Given the high stress environment of call centres, and the monotonous nature of work, call centre managers should be encouraged to offer stress-relieving interventions such as frequent parties, casual dress day, beauty parades, table tennis facilities, etc. Indeed, it is important to integrate fun and games at work, as this has been shown to be an effective attraction tool (see Rajawat, 2005).

7. Family Involvement: Given that most of employees are young individuals, inviting their parents/family to the campus, could help create a better image of call centre sector. Indeed, some of the organizations have created events like 'family day,' and report noticeable improvement in employee involvement and performance, as their families now view their jobs as potential careers and not ' a stop gap career option'.

8. Employee Welfare: Perhaps because most employees in the call centres are young, many of the organisations seem to have paid little attention to welfare and healthcare measures. However, given the stress often caused by the nature of work, organisations need to pay special attention to 
this need. Relatedly, call centre frontline employees often need psychological counselling and training in anger-management courses.

9. Cultural Sensitivity Training: Given the increasing number of foreigners now employed in these centres, there is a need to address the multicultural environment, and help both multicultural Indians and foreigners adjust. Further, this would also help operators interact better with the diverse clientele.

10. Anti-poaching Policy: A recent development has been the signing and implementing of a non-poaching agreement by the top 14 call centres (BPOs). Given that there are literally hundreds of such organizations operating (and new ones opening almost daily); this policy will help alleviate some of the concerns of attrition.

Besides these internal marketing interventions, we suggest that government assistance is also a key factor, which contributes to the healthy growth of this sector in India. With the increasing costs for hiring, training and retaining employees in the Indian call centres, there is a need for the Indian government to intervene and help in this regard. Given that the call centre industry has put India on the world economic map, there is a need for governmental assistance to support training, as is done in Singapore (see Debrah et al., 2000). The Indian government should either reimburse companies for the cost of training, or put into place required training courses either through the private sector or primary, secondary and tertiary education in the country.

It is crucial for Indian call centre organisations to find out ways, as part of the "internal marketing strategy", to ensure that the frontline employees are motivated to be customer-conscious, and remain committed to their organisations. We believe that our findings will be of interest to foreign firms operating in India, and those planning to start call centre operations in India. Again, we reiterate that it is crucial for organizations to pay attention to the issues raised above now rather than wait till the problem grows beyond control. 


\section{References}

Aneja, M. (2005), “Our BPO Pro is Falling for the Sexy Phirang”, The Economic Times, 14 March. http://economictimes.indiatimes.com/articleshow/msid-1050229,curpg-2.cms (Accessed on 14 March).

Bagchi, I. (2005), “10-mn Service Jobs Coming Your Way”, The Economic Times, 09 August. http://economictimes.indiatimes.com/articleshowmsid-1195399,prtpage-1.com. (Accessed on 12 August).

Bain, P. and Taylor, P. (1999), Call Centres in Scotland: An Overview. Glasgow: Scottish Low Pay Unit.

Baliga, H. (2005), "Should Indian Girls Really take the Sexual and Racial Abuse over Phone in Call Center Jobs? Are these BPO or Virtual Brothels?”, http://www.indiadaily.com/editorial/2937.asp(Accessed on 5 June).

Batt, R. (1999), "Work Organization, Technology, and Performance in Customer Service and Sales”, Industrial and Labor Relations Review, Vol. 52 No. 4, pp. 539-64.

Belt, V. (2002), “A female ghetto? Women's careers in call centres”, Human Resource Management Journal, Vol. 12 No. 4, pp. 51-66.

Berry, L.L. and Parasuraman, A. (1991), Marketing Services: Competing through Quality, The Free Press, New York, NY.

Brown, G. and Maxwell, G. (2002), “Customer Service in UK call centres: organizational perspectives and employee perceptions”, Journal of Retailing and Consumer Services, Vol. 9 No. 6, pp. 309-316.

Budhwar, P. (2001), “Doing Business in India”, Thunderbird International Business Review, Vol. 43 No. 4, pp. 549-568.

Budhwar, P. and Sparrow, P. (1997), "Evaluating Levels of Strategic Integration and Devolvement of Human Resource Management in India”, The International Journal of Human Resource Management, Vol. 8 No. 4, pp. 476-494.

Business line (2003), HR Department in Call Centres has it Hands Full. June 16.

Business line (2005), Over 100 Call Centres Exit Biz in last Three Years: NASSCOM.text. August 05.

Cacanas, Z. (2004), “Passage to India”, Human Resources, March, pp. 46-50.

Callaghan, G. and Thompson, P. (2002), "We Recruit Attitude: The Selection and Shaping of Routine Call Centre Labour”, Journal of Management Studies, Vol. 39 No. 2 pp. 233-254. 
Chanda, R. (2005), "Spreading the Benefits of BPO Growth”, The Financial Express 5 April. http://www.financialexpress.com/fe_full_story.php?content_id=87026?headline $=$ spre... (Accessed on 05/04/2005).

Chengappa, R. and Goyal, M. (2002), “House Keepers to the World”, India Today, November: pp. 18-48.

Christopher, E. (2005), “Offshoring Goes Complex, But it Pays”, The Economic Times Online, 12 January. http://economictimes.indiatimes.com/articleshow/988808.cms (Accessed on 25/01/05).

Cooper, J. and Cronin, J.J. (2000), "Internal marketing A competitive strategy for the longterm care industry”, Journal of Business Research, Vol. 48 No. 3, pp.177-181.

Cordray, K. (2005), "High retention rates bring customer benefits at SITEL Direct: Why callcenter company bucks the trend", Human Resource Management International Digest, Vol.13 No. 4, pp. 23-25.

Dean, A.M. (2004), "Rethinking customer expectations of service quality: are call centres different”, Journal of Services Marketing, Vol.18 No.1, pp. 60-77.

Debrah, Y. A., McGovern, I. \& Budhwar, P. (2000). "Complementarity or competition: The development of human resources in a growth triangle", The International Journal of Human Resource Management, Vol.11, pp.314-335.

Deery, S. and Kinnie, N. (2004), "Introduction: The Nature and Management of Call Centre Work”, in Deery, S. and Kinnie, N. (Eds.), Call Centres and Human Resource Management: A Cross-National perspective. Palgrave Macmillan, pp.1-22.

deRuyter, K., Wetzels, M. and Feinberg, R. (2001), "Role stress in call centres: Its effects on employee performance and satisfaction”, Journal of Interactive Marketing, Vol. 15 No. 2, pp. 23-35.

The Economic Times (2005), “Indian BPOs can Save \$30 bn for US”, http://economictimes.indiatimes.com/articleshow/1001907.cms (Accessed on 27 January).

The Economist (2004), “India’s Shinning Hopes: A Survey of India”, 21 February 2004.

The Economist (2005), "Survey: Sweatshops and technocoolies”, 05 March, p. 9.

European Journal of Work and Organizational Psychology (2003), Vol.12 No. 4.

The Financial Express (2005), “Call Centres Turn Women-Favourites. 08 March”, http://www.financialexpress.com/fe_full_story.php?content_id=84677?headline $=$ Call... (Accessed on 9 March) 
Forsyth, A.M. (2004), “Lloyds TSB Banks on Call-Center Quality”, Human Resource Development International Digest, Vol.12 No. 1, pp. 14.

Frenkel, S., Korczynski, M., Shire, K. and Tam, M. (1998), "Beyond Bureaucracy? Work Organization in Call Centres”, International Journal of Human Resource Management, Vol. 9, pp. 957-979.

George, S. (2005), “Are BPOs the New Age Sweatshops?”, The Economic Times, 12 May.

Grebner, S., Semmer, N.K., Faso, L.L., Gut, S., Kalin, W. and Elfering, A. (2003), "Work Conditions, Well-being, and Job-Related Attitudes among Call Centre Agents”, European Journal of Work and Organizational Psychology, Vol. 12 No. 4, pp. 341-365.

Greene, W.E., Walls, G.D. and Schrest, L.J. (1994), “Internal marketing The Key to external marketing success”, Journal of Services Marketing, Vol. 8 No. 4, pp. 5-13.

Halliden, B. and Monks, K. (2005), “Employee-centred management in a call centre”, Personnel Review, Vol. 34 No. 3, pp. 370-386.

Hannif, Z.N. and Lamm, F. (2005), Occupation Health and Safety in the New Zealand Call Centre Industry. ESC Working Paper, Department of Management and Employment Relations, University of Auckland, No. 2005/8.

Heller, F.A. (1998), “Influences at work: A 25-year program of research”, Human Relations, Vol. 51, pp. 1425-1451.

Heskett, J.L., Jones, T.O., Loveman, G.W., Sasser, W.E. Jr. and Schlesinger, L.A. (2008), "Putting the service-profit chain to work", Harvard Business Review, July-Aug, pp. 118129 (hbr.org)

The Hindu (2005a), “UK Firms Save 10mn Pounds for Every 1000 Offshored Jobs”, 25 January.

The Hindu (2005b), “Indian Quit Call Centers due to Racial Abuse”, 29 May.

Holtgrewe, U.C., Kerst, C. and Shire, K. (2002), Reorganizing Service Work: Call Centres in Germany and Britain. Burlington: Ashgate.

Houlihan, M. (2004), “Tensions and Variations in Call Centre Management Strategies”, in Deery, S. and Kinnie, N. (Eds.), Call Centres and Human Resource Management: A Cross National perspective. Palgrave Macmillan, pp.75-101.

Human Resource Management Journal (2002), Vol. 12 No. 4.

Hutchinson, S., Purcell, J. and Kinnie, N. (2000), "Evolving high commitment management and the experience of the RAC call centre”, Human Resource Management Journal, Vol. 10 No. 1, pp. 63-78. 
International Journal of Service Industry Management (2000), Vol. 11 No. 2.

Jayachandran, C. (2005), "Indian Call Centers to Swell with Foreigners Soon”, http://www.hinsustantimes.com/news/181_1389630,001300460000.htm?headline=In... (Accessed on 6 June).

Jayaswal, R. (2005), “GenY Logs out of BPO Honeymoon”, The Economic Times, 14 February. http://economictimes.indiatimes.com/articleshow/102980.cms?headline $=$ GenY logs... (Accessed on 23 February).

Jha, R. (2005), “Job Hoppers Beware! BPOs Switch to Combat Mode”, The Economic Times, 24 June.http://economictimes.indiatimes.com/articleshow/msid-1150751,prtpage-!.cms (Accessed on 24 June).

Khatri, N., Budhwar, P. and Fern, C.T. (2001), "Explaining Employee Turnover in an Asian Context”, Human Resource Management Journal, Vol. 11 No. 1, pp. 54-74.

Kinnie, N., Purcell, J. and Hutchinson, S. (2000), "Managing the Employment Relationship in Telephone Call Centres”, in Purcell, J. (Ed.), Changing Boundaries in Employment. Bristol: Bristol Academic Press.

Lewig, K.A. and Dollard, M.F. (2003), “Emotional Dissonance, Emotional Exhaustion and Job Satisfaction in Call Centre Workers”, European Journal of Work and Organizational Psychology, Vol. 12 No. 4, pp. 366-392.

Malhotra, N. and Mukherjee, A. (2004), “The relative influence of Organizational Commitment and job satisfaction and job satisfaction on service quality of customer-contact employees in banking call centres”, The Journal of Services Marketing, Vol.18 Nos. 2/3, pp.162-183.

Mattson, J. (1994), “Improving service quality in person-to-person encounters”, The Service Industries Journal, Vol. 14 No.1, pp. 45-61.

Meyer, J.P. and Smith, C.A. (2000), "HRM practices and organizational commitment: Test of a mediation model”, Canadian Journal of Administrative Sciences, Vol. 17 No. 4, pp. 319-331.

Mukherjee, A. and Malhotra, N. (2006), "Does role clarity explain employee-perceived service quality? A study of antecedents and consequences in call centres", International Journal of Service Industry Management, Vol. 17 No. 5, pp. 444-473.

NASSCOM (2005a), “BPO Job Potential Stays High”, NASSCOM. Sify.com http://sify.com/finance/fullstory.php?id=13866657?headline $=B P O \sim j o b \sim$ potential $\sim$ sta (Accessed on 8/6/05).

NASSCOM (2005b), http://nasscom.org/artdisplay.asp?Art_id=2781 (Accessed on 24 May). 
Pande, B. (2005), “Sun, Survey Can't Deter the Call of Duty”, The Economic Times Online, 29 July. http://economictimes.indiatimes.com/articleshow/msid-1185174, (Accessed on $5 / 08 / 05)$.

Prahalad, C.K. (2005), “The Art of Outsourcing”, The Wall Street Journal, Easter Edition, 8 June, A14.

Punch, L. (2004), “The Global Back Office: Beyond the Hype”, Credit Card Management, Vol. 16 No. 11, pp. 26.

Quester, P.G. and Kelly, A. (1999), "Internal marketing practices in the Australian financial sector: An exploratory study”, Journal of Applied Management Studies, Vol. 8 No. 2, pp. 217-229.

Rafiq, M. and Ahmed, P.K. (2000), “Advances in the internal marketing concept: definition, synthesis and extension”, Journal of Services Marketing, Vol. 14 No. 6, pp. 449-462.

Rajawat, K.Y. (2005), “Ajay Devgan Syndrome Haunts Desi BPO Crowd”, The Economic Times, 12 August. http://economictimes.indiatimes.com/articleshow/msid-1198413,prtpage1.cms (Accessed on 12 August).

Ramchandran, K. and Voleti, S. (2004), "Business Process Outsourcing (BPO): Emerging Scenario and Strategic Options for IT-enabled Services”, Vikalpa, Vol. 29 No. 1, pp. 4962.

Read, B.B. (2001), "Being there: Serving your US customers from afar”, Call Centre Magazine, Vol. 14 No. 2, pp. 85-92.

Rediff.com (2005a), "What Indian BPO Industry Needs", http://us.rediff.com/money/2005/apr/23bpo.htm (Accessed on 01 July).

Rediff.com (2005b), “1000 Jobs Offshored = 10mn Saved!”, http://us.rediff.com/money/2005/jan/24bpo.htm?headline $=B P O: \sim 1000 \sim j o b s=\sim £ 10 \sim$... (Accessed on 25 January).

Robinson, G. and Morley, C. (2006), "Call centre management: responsibilities and performance”, International Journal of Service Industry Management, Vol. 17 No. 3, pp. 284-300.

Rose, E. and Wright, G. (2005), "Satisfaction and dimensions of control among call centre customer service representatives", The International Journal of Human Resource Management, Vol. 16 No. 1, pp. 136.

Rubery, J., Carroll, M., Cooke, F.L., Grugulis, I. and Earnshaw. J. (2004), "Human Resource Management and the Permeable Organization: The Case of the Multi-Client Call Centre”, The Journal of Management Studies, Vol. 41 No. 7, pp.1199-1221. 
Russell, B. (2002), “The Talk Shop and Shop Talk: Employment and Work in a Call Centre”, The Journal of Industrial Relations, Vol. 44 No. 4, pp. 467-490.

Sangameshwaran, P. and Rai, A.R. (2005), “Are Indian BPOs Losing Their Cutting Edge?”, Business Standard, Tuesday, 22 March.

Schneider, B. (1991), “Service quality and profits: can you have your cake and eat it too?”, Human Resource Planning, Vol. 14 No. 2, pp.151-157.

Schneider, B. and Bowen, D. (1995), Winning the Service Game, Harvard Business School Press, Boston.

Sergeant, A. and Frenkel, S. (2000), "When do customer contact employees satisfy customers?”, Journal of Service Research, Vol. 3 No.1, pp. 18-34.

Shastri, R. (2004), “The Economics of Indian Call Center Model”, Customer Inter@action Solutions, Vol. 23 No. 5, pp. 58-61.

Shushmul, P. (2005), “When Sick Leave is Rampant and Attrition Soars High”, Callcentre helper.com (Accessed on 14 July).

Sifynews (2005), "Women can Now Work Late Night Shifts”, http://headlines.sify.com/news/fullstory.php?id=13704363\&headline $=$ Women $\sim$ can $\sim n .$. . (accessed on 19 March).

Singh, J. (2000), "Performance productivity and quality of frontline employees in service organizations”, Journal of Marketing, Vol. 64, April, pp.15-34.

Singh, H. (2005a), “Is the BPO Iceberg Melting Under Attrition Heat?”, The Economic Times, 10 February.

Singh, H. (2005b), “Circa 2010: KPO v/s BPO, KPO Wins”, The Economic Times, Friday, 11 March.http://economictimes.indiatimes.com/articleshow/1057153.cms?headline=Move o ver... (Accessed on 21/03/05).

Stanworth, C. (2000), "Women and work in the information age", Gender, Work and Organization, Vol. 7 No.1, pp. 20-32.

Subramanyam. R. (2004), “Job Hopping Plagues IT Sector”, The Economic Times, 28 September. http://economictimes.indiatim../865874.cms?headline $=$ Job $\sim$ hopping plagues $\sim$ IT $\sim$ secto (Accessed on 28 September).

Taylor, P. and Bain, P. (2005), "India Calling to the Far Away Towns: The Call Centre Labour Process and Globalization”, Work, Employment and Society, Vol. 19 No. 2, pp. 261-282.

Taylor, P. and Bain, P. (1999), “An Assembly Line in the Head: The Call Centre Labour Process”, Industrial Relations Journal, Vol. 30 No. 2, pp.101-117. 
Taylor, S. and Tyler, M. (2000), "Emotional Labour and Sexual Difference in the Airline Industry Work”, Employment and Society, Vol. 14 No. 1, pp. 77-95.

Taylor, P., Mulvey, G., Hyman, J. and Bain, B. (2002), "Work Organization, Control and the Experience of Work in Call Centres”, Work, Employment and Society, Vol. 16 No.1, pp. 133-150.

Tuten, T.L. and Neidermeyer, P.E. (2004), "Performance, satisfaction and turnover in call centers: The effects of stress and optimism”, Journal of Business Research, Vol. 57 No.1, pp. 26-34.

Varma, A., Srinivas, E.S. and Stroh, L.K. (2005), “A comparative study of the impact of leader member exchange relationships in U.S. and Indian samples”, Cross-Cultural Management: An International Journal, Vol. 12 No. 1, pp. 84-95.

Verma, P. (2005), “BPOs Now Go in for Multi-City Back-ups”, The Economic Times, 05 August. http://economictimes.indiatimes.com/articleshow/msid-1191479,prtpage-1.cms (Accessed on 05 August).

Wadhwa, R. (2004), “Oh Honey! I Need a Good Night’s Sleep”, The Economic Times, 04 August. http://economictimes.indiatimes.com/articleshow/msid-1190225,prtpage-1.cms (Accessed on 5 August).

Walletwatch (2003), "Call Centre Attrition puts HR Managers to Test”, http://www.samachar.com/biz/fullstory.html (Accessed on 08 May 2003).

Wilkinson, A. (1998), “Empowerment: Theory and practice”, Personnel Review, Vol. 27, pp 40-56.

Witt, L.A., Andrews, M.C. and Carlson, D.S. (2005), "When Conscientiousness Isn't Enough: Emotional Exhaustion and Performance among Call Center Customer Service Representatives”, Journal of Management, Vol. 30 No. 1, pp. 149. 


\begin{tabular}{|c|c|c|}
\hline & Table I: Factors Related to Turnover in Call Centres in India & Agreement (\%) \\
\hline 1 & Jobs have to be an enriching experience. & 88.6 \\
\hline 2 & Pay and incentives are important for you. & 87.6 \\
\hline 3 & You are highly committed to your work. & 86.6 \\
\hline 4 & The call centre job is a physically draining one. & 79.1 \\
\hline 5 & $\begin{array}{l}\text { Pay and incentives are the reason for the high attrition rates in the call } \\
\text { centres. }\end{array}$ & 78.6 \\
\hline 6 & $\begin{array}{l}\text { You have heard cases and friends quitting the job on the grounds of } \\
\text { health. }\end{array}$ & 77.5 \\
\hline 7 & The call centre job has affected your health in some way or the other. & 76.1 \\
\hline 8 & Money is the ultimate motivator. & 71.7 \\
\hline 9 & Your current job is an enriching experience. & 71.5 \\
\hline 10 & $\begin{array}{l}\text { Your managers and team leaders help you and the other agents to handle } \\
\text { these tough agents. }\end{array}$ & 70.1 \\
\hline 11 & Customers over the phone get unreasonable and irritating. & 71 \\
\hline 12 & Late night shifts are not that big a problem for you. & 70 \\
\hline 13 & $\begin{array}{l}\text { You are using this job to gain experience and bridge your academic } \\
\text { career. }\end{array}$ & 69.8 \\
\hline 14 & You regard the competition in your call centre as a healthy one. & 69.5 \\
\hline 15 & Irritating and abusive customers often get to your nerves. & 68.8 \\
\hline 16 & $\begin{array}{l}\text { If you feel that the call centre job is boring and monotonous, it is one of } \\
\text { the reasons for you to quit. }\end{array}$ & 68.6 \\
\hline 17 & $\begin{array}{l}\text { The appraisal system in your organisation is a one to one } \\
\text { communication/interaction, than a one way download system. }\end{array}$ & 68.1 \\
\hline 18 & You find your job satisfactory and enjoyable. & 65.6 \\
\hline 19 & You would be keen on making a career out of a call centre job. & 65.1 \\
\hline 20 & $\begin{array}{l}\text { You have seen that handling these tough customers often breaks the } \\
\text { toughest of the agents. }\end{array}$ & 63.6 \\
\hline 21 & $\begin{array}{l}\text { You are satisfied with the performance appraisal system in your } \\
\text { organisation. }\end{array}$ & 58.6 \\
\hline 22 & Are uneasy colleagues responsible for making your job an uneasy one? & 56.3 \\
\hline 23 & You are satisfied with the pay and incentives offered by your company. & 53.2 \\
\hline 24 & You feel that the call centre job can not get any better. & 52.8 \\
\hline 25 & $\begin{array}{l}\text { You are content with the career planning and development prospects } \\
\text { within your organisation. }\end{array}$ & 50 \\
\hline 26 & $\begin{array}{l}\text { Does the 'race to be the best' and the competition involved, make you } \\
\text { uncomfortable? }\end{array}$ & 47.8 \\
\hline 27 & You are satisfied in the way the management takes care of your health. & 46.8 \\
\hline 28 & $\begin{array}{l}\text { Free tea and coffee, T.V. and the parties are enough for you to stay } \\
\text { effective, motivated and efficient. }\end{array}$ & 42.8 \\
\hline
\end{tabular}




\begin{tabular}{|l|l|c|}
\hline \multicolumn{2}{|c|}{ Table II: Employee Involvement Practices in Call Centres in India } \\
\hline $\mathbf{1}$ & Devolvement of task or operational decision-making to the lowest level & $16 \%$ \\
\hline $\mathbf{2}$ & Devolvement of responsibility for quality to the lowest level & $59 \%$ \\
\hline $\mathbf{3}$ & Autonomous work groups/ Quality circles or groups & $90 \%$ \\
\hline $\mathbf{4}$ & Newsletters / In-House publications & $43 \%$ \\
\hline $\mathbf{5}$ & Corporate intranet & $90 \%$ \\
\hline $\mathbf{6}$ & Team Meetings & $98 \%$ \\
\hline $\mathbf{7}$ & Employee forums or focus groups & $67 \%$ \\
\hline $\mathbf{8}$ & Management presentations & $61 \%$ \\
\hline $\mathbf{9}$ & Suggestion schemes & $88 \%$ \\
\hline $\mathbf{1 0}$ & Employee opinion surveys & $57 \%$ \\
\hline $\mathbf{1 1}$ & Works councils or other consultative committees/ Trade Union representation & $15 \%$ \\
\hline
\end{tabular}




\begin{abstract}
About the authors
Prof. Pawan Budhwar is a Professor of International Human Resource Management and head of Work and Organizational Psychology Group at Aston Business School, Birmingham, UK. He is also the director of Aston India Foundation for Applied Business Research and Aston Centre for Human Resources. Pawan received his doctorate from Manchester Business School. Before joining Aston University in 2003 he taught for 6 years at Cardiff Business School and for 5 years at Institute of Management Studies and Research, Rohtak, India. Pawan has published extensively in the fields of HRM, International HRM, Organizational Behaviour and developing countries with a specific emphasis on India.
\end{abstract}

Prof. Arup Varma is a Professor of HRM at the School of Business Administration, Loyola University Chicago. He received his doctorate from Rutgers University. Before joining Loyola University in 1996, he worked the human resource area for over 6 years. His research interests include performance appraisal and expatriate issues. He has published numerous papers in leading journals such as Academy of Management Journal, Journal of Applied Social Psychology and Human Resource Management.

Dr. Neeru Malhotra is a Senior Lecturer at Aston Business School, Aston University, Birmingham, UK. Dr. Malhotra has published in many internationally recognized journals, such as the International Journal of Service Industry Management, Journal of Services Marketing, Journal of Marketing Management, The Service Industries Journal, and International Journal of Human Resources Management. Dr. Malhotra has been awarded the Best Paper Award in the Services Marketing Track at the Academy of Marketing Conference in 2003 and the Emerald Literati Highly Commended Award in 2007 for two of her publications. 